\title{
Spain: Underwater Exploration on a Narrow Continental Shelf
}

\author{
Pablo Arias
}

\section{Abstract}

In spite of Spain's long coastline (nearly $8000 \mathrm{~km}$ ) and its well-established tradition in underwater archaeology, the prehistoric settlement of the continental shelf is practically unknown with very few finds. Underwater research has focused on naval archaeology and, until very recently, no attempt had been made to look for prehistoric underwater sites. In the past decade, new research projects have been launched to explore selected areas on the Cantabrian shelf and offshore of Gibraltar. This chapter summarises the currently available evidence of submerged prehistoric archaeology and the preliminary results of these new projects.

\section{Keywords}

Continental shelf $\cdot$ Submerged landscapes ·

Neanderthal · Mousterian · Upper Palaeolithic - Mesolithic $\cdot$ Neolithic $\cdot$ Bronze Age $\cdot$ Votive deposits

\subsection{Introduction ${ }^{1}$}

Occupying roughly five sixths of a large peninsula, Spain has a long coastline of some $7905 \mathrm{~km}$. This includes Atlantic and Mediterranean-facing shores-1075 km in the Bay of Biscay, $1761 \mathrm{~km}$ facing the Atlantic Ocean and $2058 \mathrm{~km}$ along the Mediterranean Sea, plus $1428 \mathrm{~km}$ in the Balearic Islands and $1583 \mathrm{~km}$ in the Canary Islands. Moreover, some of the most fertile regions and largest concentrations of population are in coastal regions, so Spain can be defined as a maritime country. From another point of view, the Iberian Peninsula, located at a geographic crossroads of Europe, was densely populated throughout prehistory and possesses some of the most important Palaeolithic sites in Europe, notably the caves of northern and south-eastern Spain and Gibraltar, a very high density of Mesolithic coastal sites and important cultures of the Neolithic, Bronze and Iron Ages. This suggests considerable potential for research on the prehistoric settlement of the continental shelf.

As a largely coastal country, it is not surprising that Spain enjoys a rich tradition in the field

\footnotetext{
${ }^{1}$ The Iberian Peninsula comprises the sovereign states of Spain, Portugal and Andorra and the British Overseas Territory of Gibraltar. In terms of its Stone Age prehistory, it forms a single geographical entity. For convenience, the evidence from Portugal is considered separately in Chapter 14, and that from Gibraltar is included in this chapter.
}

P. Arias $(\bowtie)$

Instituto Internacional de Investigaciones

Prehistóricas de Cantabria, Universidad de Cantabria-

Gobierno de Cantabria-Santander, Santander, Spain

e-mail: pablo.arias@unican.es 


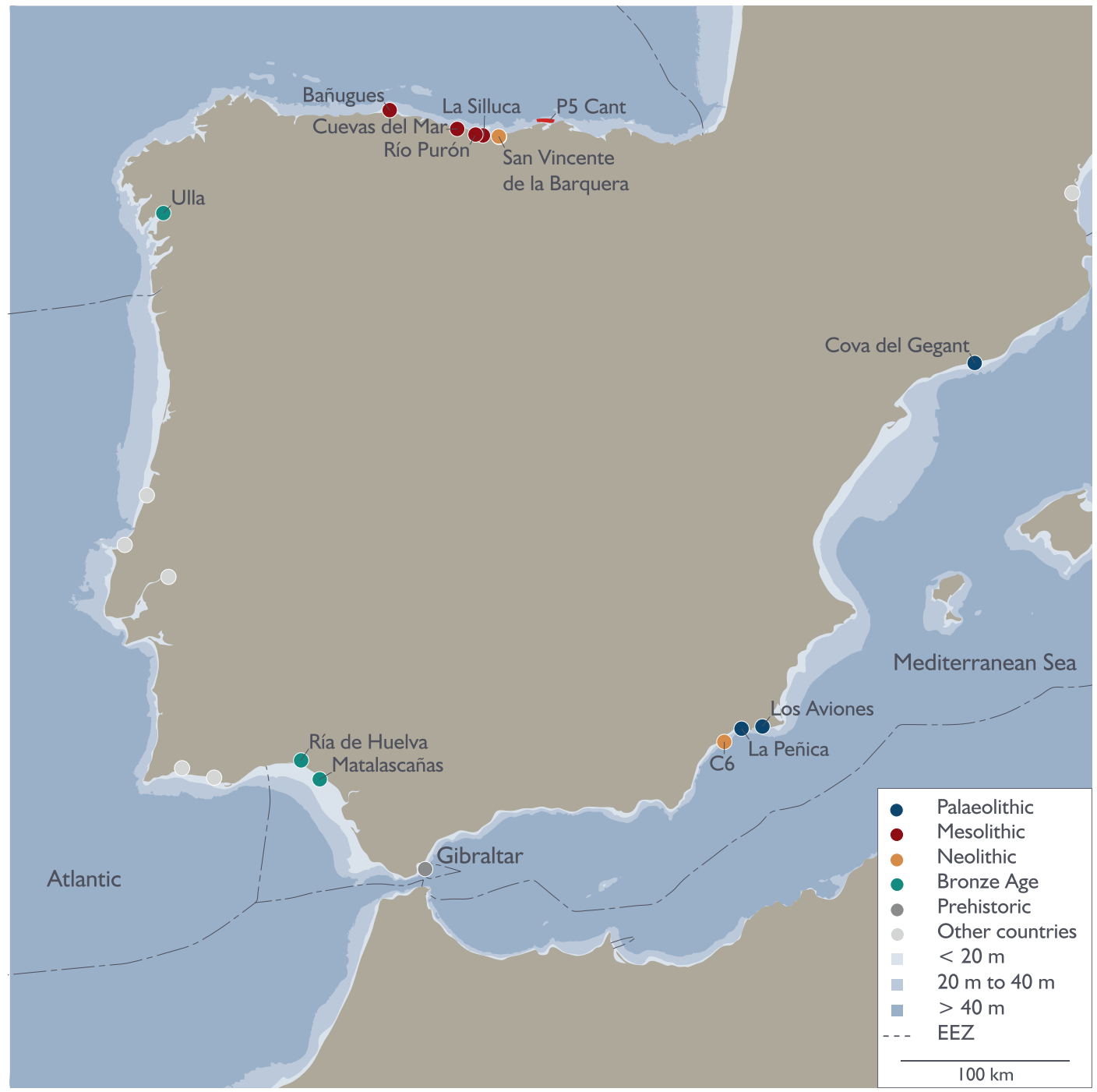

Fig. 13.1 Location of sites and research projects mentioned in the text. Site information from the SPLASHCOS Viewer http://splashcos-viewer.eu. Drawing by Moritz Mennenga

of underwater archaeology (Blánquez and Martínez Maganto 1993; Nieto 2009; Nieto and Bethencourt 2014). This has focused on naval history, with hundreds of shipwrecks and other remains of trade and warfare from the Phoenician, Greek and Roman periods and from the Modern Age, when the Spanish Crown became one of the world's main naval powers, all of which are well represented in the recently refurbished National Underwater Archaeology Museum (Museo Nacional de Arqueología
Subacuática-ARQUA) in Cartagena. There is a small but significant number of underwater finds ranging from the Palaeolithic to the Bronze Age, mostly discovered by chance (Fig. 13.1), and recent projects dedicated to underwater survey of the continental shelf, which suggests considerable potential for future discoveries. This chapter summarises data on known prehistoric underwater sites, the results of recent offshore surveys and the potential for future research. 


\subsection{Conditions of Preservation and Discovery}

One of the deterrents to underwater investigation on many coastlines, especially those in the Bay of Biscay associated with the large concentrations of Palaeolithic sites in the Cantabrian region, is that sea conditions are challenging for underwater archaeological exploration and potentially unfavourable for the preservation of prehistoric remains, due to strong currents, large waves and a predominance of erosional processes over sedimentation (Moura et al. 2017). Moreover, administrative responsibility for the continental shelf is divided between a number of regional and central government agencies, leading to considerable bureaucratic complexities in the organisation of underwater work aimed at the search for submerged landscapes, and these can act as a further disincentive. Although Spain is not formally a federal state, the regions (autonomous communities) hold considerable legislative and administrative power in numerous fields. One of them is culture, and particularly archaeology, which has been fully devolved to the regions (Martínez Díaz 1992, 1993). However, the management of the continental shelf is the exclusive responsibility of the central government. This duality causes considerable bureaucracy and also hinders the rational planning of research and protection of the heritage, as conflicts of authority and demarcation disputes between the different administrations can easily occur. ${ }^{2}$ In fact, despite a few attempts (directed mainly towards naval archaeology), a national management plan for underwater archaeology has still not been devised.

Another factor that has to some extent deterred interest and investigation in offshore prehistoric

\footnotetext{
${ }^{2}$ As an example, the P5 Cant Project, described below, required permission from three state organisations (Harbour Master's Office, Port of Santander and Civil Guard), two regional government organisations (Directorate General of Culture and Directorate General of Fishing and Food), a hospital (belonging to another department of the regional government) because of safety regulations associated with diving and the Santander Town Corporation (for permission to place a geolocation aerial on land).
}

material is the fact that the Spanish continental shelf is quite narrow (Fig. 13.1); apart from Galicia in the north-west and sections of the Mediterranean coast, relatively little territory has been submerged by postglacial sea-level rise, especially in comparison with northern Europe, weakening the incentive to conduct underwater investigation on the assumption that it would make little difference to current understandings of Palaeolithic and Mesolithic patterns of settlement and adaptation.

This is counterbalanced by a series of positive factors. In the first place, on many coastlines, there is a high density of Palaeolithic and Mesolithic sites. This is especially true of Cantabrian Spain, which displays the highest concentration of coastal Palaeolithic sites in Europe (Straus 1992, 2018; Fano 2004). The density of Mesolithic sites is even higher: in eastern Asturias, around 130 sites have been recorded along only $50 \mathrm{~km}$ of coast (see Fano 2004, Arias and Fano 2009). On the other hand, the continental shelf is particularly narrow, averaging $15 \mathrm{~km}$, so the hypothesis can be proposed that the recorded Palaeolithic sites on land are just a part of a larger coastal settlement system which is not too extensive to be explored efficiently but which may include important evidence of sites and activities that are not represented on land in the present-day coastal region. In fact, there is indirect evidence showing that Palaeolithic groups in Cantabrian Spain and elsewhere maintained regular contact with the sea. Even at the maximum lowering of sea level at the Last Glacial Maximum, the shoreline was within quite easy reach of coastal caves that are on or close to the present-day coastline. Some of these coastal caves have stratified deposits with cultural material that reach back to the time of the Last Glacial Maximum or earlier, and it is clear from the faunal remains in these earlier deposits that the now submerged plain was a very significant area of lowland territory for the large mammals that formed an important part of the Palaeolithic subsistence economy and an important part of the territory used by the occupants of these cave sites.

The submerged coastline was also a source of marine foods and close enough to the present-day 
shoreline that some of these resources were brought back to caves on the modern coast for processing and consumption. Mollusc shells, in particular, are present in these Palaeolithic deposits, and sometimes quantities of fish bone, for example, at La Riera Cave in Asturias (Straus and Clark 1986), Nerja and Bajondillo in Andalusia (Morales et al. 1998; Cortés-Sánchez et al. 2008, 2011) and Gorham's Cave and Vanguard Cave on the Gibraltar Peninsula (Finlayson et al. 2006; Stringer et al. 2008). Occasionally, remains of marine mammals such as seals or cetaceans are also recorded (Corchón et al. 2008; ÁlvarezFernández 2011; Álvarez-Fernández et al. 2014; Morales et al. in press). The quantities of marine food remains in these Palaeolithic deposits are not as great as those present in later deposits, such as the Asturian shell middens, many of

a

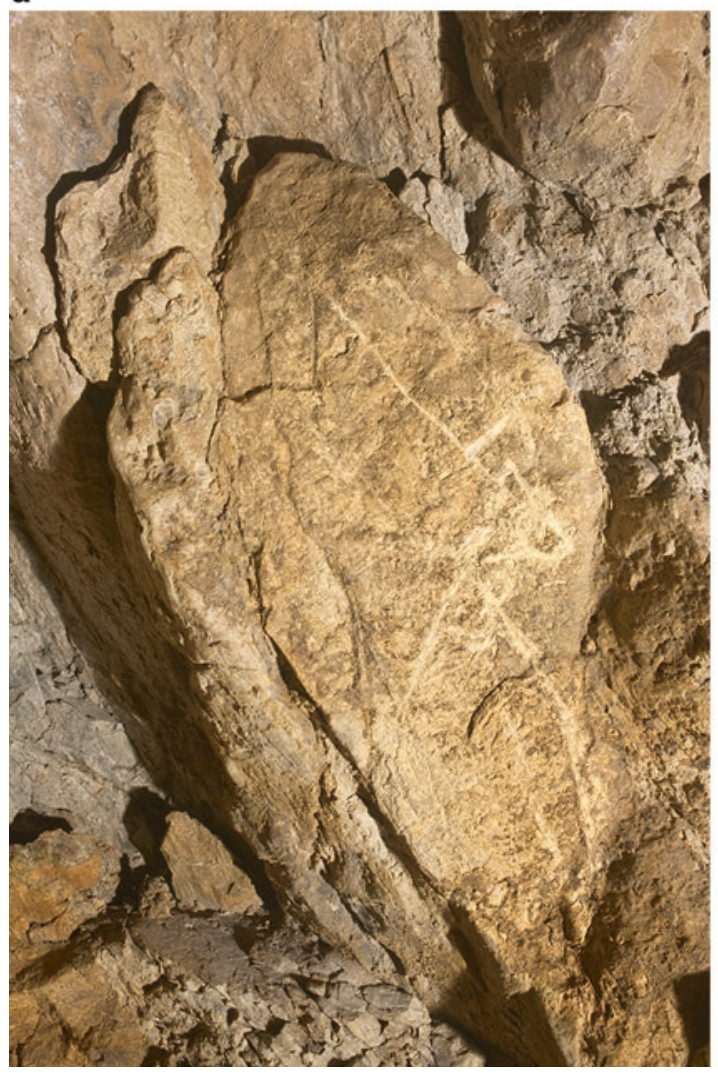

which fill the mouths of small caves and are stratified above deposits with Palaeolithic cultural remains (González Morales 1982). However, that may simply reflect the greater distance between these sites and the contemporaneous palaeoshorelines of the Palaeolithic and early Mesolithic period and the likelihood that only a portion of the marine catch was carried inland while the rest was processed and consumed closer to the coastline and left its archaeological mark on sites that are now submerged (Bailey and Craighead 2003).

Other evidence of contact with the coast during periods of lower sea level is the existence of depictions of marine animals in Palaeolithic art, such as the representations of fish on the walls of El Pindal (Alcalde del Río et al. 1911; Morales and Roselló 1984-1985) and Altxerri (Fig. 13.2; Altuna 1997) or portable art objects, notably the

b

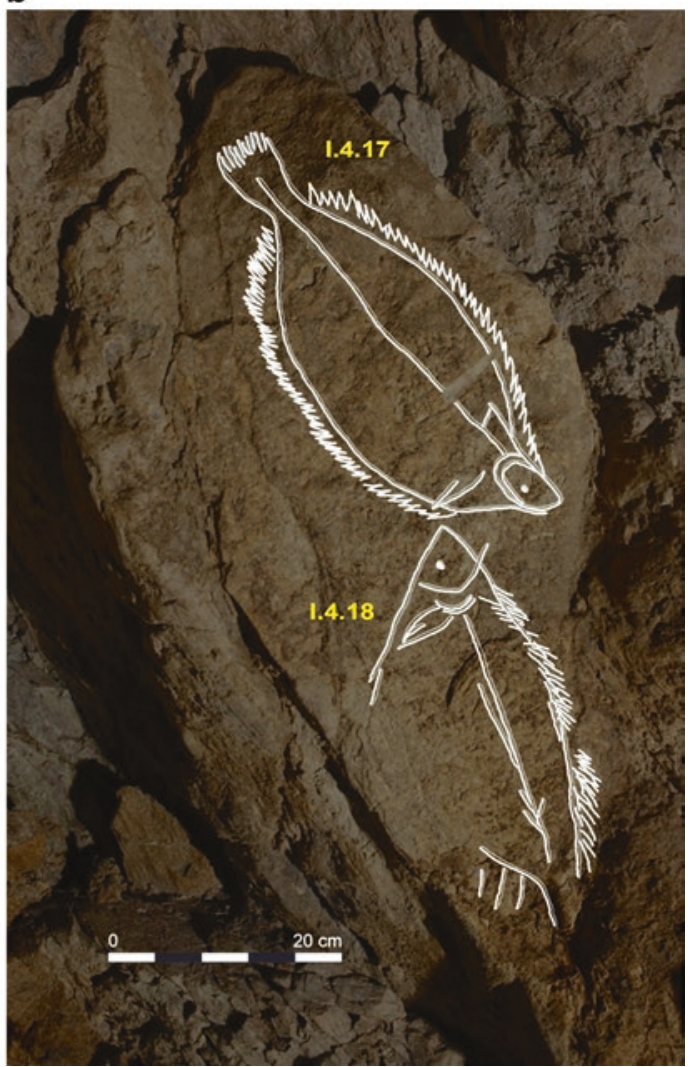

Fig. 13.2 Rock engravings representing Pleuronectiform fish (probably flounder-Platichthys flesus) on the walls of the cave of Altxerri (Basque country). (a) Photo of the engravings. (b) The same image with the outlines of the fish highlighted and a scale added. Photo by J. Altura and X. Otero; interpretation after Ruiz 2014 


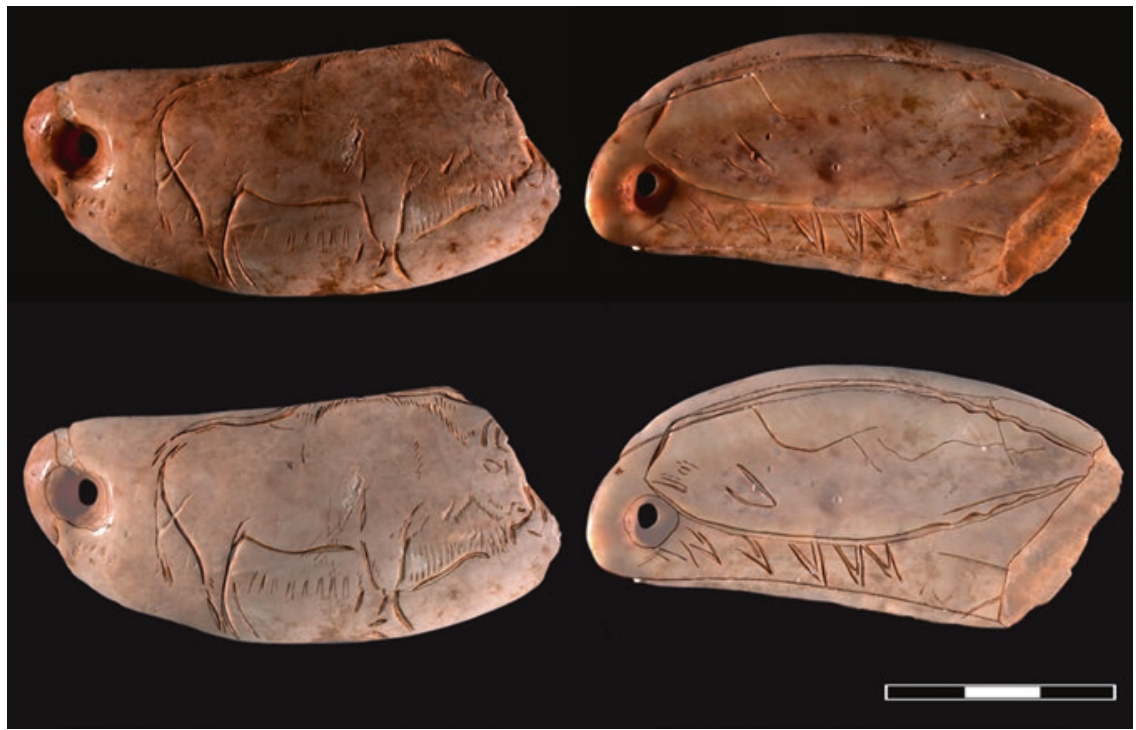

Fig. 13.3 Representation of a bison and a whale on a sperm whale tooth from layer VIIIb (middle Magdalenian) of the cave of Las Caldas (Asturias). Scale in $\mathrm{cm}$. Photo of the original (upper row) and digitally enhanced interpretation of the photo (lower) after Rivero 2015

representation of a cetacean on a sperm whale tooth from the cave of Las Caldas in Asturias (Fig. 13.3; Rivero 2015; Corchón 2017). Moreover, isotopic values demonstrate marine diet for some individuals (unpublished results from Cueva de Los Canes in Asturias). All of these suggest that the submerged areas of continental shelf were densely occupied and that the narrowness of the submerged shelf is, therefore, an incentive to more detailed underwater exploration rather than a deterrent.

A third advantage of working offshore, and this is well demonstrated on the Cantabrian coast, is that the region is rich in karst geology, which in some cases continues beneath the sea, and these are good environments for human settlement and for the preservation of archaeological remains. Similar comments apply to other coastlines, particularly in south-east Spain and Gibraltar. The presence of numerous occupied caves and rockshelters in these regions of karst geology raises the prospect of discovering submerged cliff lines with caves where terrestrial deposits may have been protected from the destructive effects of sea-level rise (see also Canals et al. 2017).

Mention should also be made of inland lake basins. These offer good examples of underwater preservation. The most important of these is Lake Banyoles (Catalonia). Here, a large-scale research project at the early Neolithic site of La Draga has documented a settlement of one of the earliest farming communities in the western Mediterranean, with magnificent preservation of organic remains such as wooden artefacts and plant fibres, dating between c. 5300 and 5000 cal BC (Bosch et al. 2000, 2011, 2012; Piqué et al. 2015). Other examples are the Mesolithic sites of Albufera de Anna in Valencia (Aparicio 1975) and some megalithic monuments flooded by reservoirs in Extremadura (Matamoros et al. 2013-2015).

\subsection{Archaeological Overview}

\subsubsection{Palaeolithic and Mesolithic Finds}

One interesting case, because of its potential, is La Peñica or Punta del Faro, a poorly known site that was found in 1980 when the port of Puerto de Mazarrón in Murcia was being dredged. Here, at $3.5 \mathrm{~m}$ depth, beneath a layer with Roman material, was a Palaeolithic deposit overlying a fossil 
beach. The artefacts appear to have been eroded from a nearby rockshelter and are of Middle Palaeolithic affinity, but no further details are available (Montes 1985, 1989). Also in the same region, there is the cave of Los Aviones near Cartagena, where a Mousterian deposit is being eroded from the cave by wave action (Montes 1985, 1989, 1991).

Other cases are known of totally or partially flooded caves in which strata or at least prehistoric materials have been documented. Of particular interest is the cave site of Cova del Gegant near Sitges, south of Barcelona (Daura et al. $2005,2010)$. The cave is partly above modern sea level but is only accessible by sea or from above through a narrow, vertical chamber. The deposits inside the cave have been partially eroded by wave action, but some sediments are slightly above sea level and have preserved a stratigraphy with a time span of c. 100-40 ka, with remains of Pleistocene fauna, Mousterian artefacts, a Neanderthal mandible with a uranium series date of $52.3 \pm 2.3 \mathrm{ka}$ and some isolated Neanderthal teeth.

We can also mention some Mesolithic sites on the coast of the Bay of Biscay such as La Silluca, Cuevas del Mar and Río Purón (Llanes), which consist of Asturian shell middens located in caves which are currently flooded at high tide (González Morales 1982). A similar case on the Mediterranean coast is Cave C-6 near Cape Cope (Águilas, Murcia), where late Neolithic remains have been found (San Nicolás and Martínez 1987).

More difficult to interpret are the prehistoric remains that have appeared on beaches, of which there are numerous Mesolithic examples, for example, at Bañugues and other sites in the Cape Peñas area of Asturias (Blas et al. 1978) and in the Mongrí area of Gerona. It is difficult to determine whether these represent materials eroded out from submerged coastal sites and redeposited on the shore or more simply reflect the concentration of Mesolithic activities along the presentday shoreline.

Mention should also be made of the remains of Pleistocene fauna that have been occasionally dredged up by fishing boats at different points on the Spanish continental shelf, such as the probos- cidean teeth from Catalonia mentioned by Canals et al. (2017, pp. 323-324). However, unless it can be clearly established that they can be related to human activity, they should be regarded as palaeontological deposits, as is the case with the above examples, which include species such as the mastodon which were extinct before the arrival of hominins in the Iberian Peninsula.

\subsubsection{Neolithic and Bronze Age Votive Deposits}

A number of finds fit into this category, although most are accidental discoveries resulting from commercial fishing or dredging. The only known find associated with systematic archaeological activity is a Neolithic polished axe recovered in an underwater survey in the port of San Vicente de la Barquera in Cantabria (Casado et al. 1992). A copper axe was found in the same area, at Puente de la Maza (Jorge 1953; Arias et al. 2005).

The most significant case in an offshore context of this kind is a late Bronze Age carp's tongue sword, picked up in a fisherman's net two miles off the coast between Matalascañas and Mazagón, Huelva (Meijide 1988, p. 113).

Other finds were discovered in estuaries or ports by dredging and therefore have limited or non-existent contextual information. The most significant of these is the Ría de Huelva hoard, found in a large estuary formed by the confluence of the Rivers Tinto and Odiel. Here, in 1923, a dredger found one of the most significant late Bronze Age assemblages in Europe, a fundamental reference for the transition from Late Bronze Age 2 to 3, the Blackmoor/Braud/Huelva phase according to the seriation proposed by Brandherm (2007; see also Burgess and O'Connor 2008 and Brandherm and Burgess 2008). It comprises 400 objects, including 88 swords or sword fragments, 29 daggers, 85 spearheads, 49 ferrules and arrowheads, 4 helmets and 9 elbow fibulae, buttons, fasteners, pins, torc fragments and harness elements. For many years, this assemblage was attributed to a Bronze Age shipwreck (Almagro 1940, 1958). However, a later reappraisal (RuizGálvez 1995) suggests that it is an example of a 
Bronze Age hoard (Bradley 1990). From this point of view, the Huelva material may be interpreted as a votive offering deposited in an estuary in the late tenth century cal BC.

A similar example occurs in the estuary of the River Ulla in Galicia, where dredging recovered a large group of Late Bronze Age objects: at least two rapiers, five swords, two palstaves and a spearhead (Ruiz-Gálvez 1982; Peña 1985). It is possible that we can add to this list some swords recovered in the large area, currently emerged, corresponding to the former estuary of the River Guadalquivir.

\subsection{New Projects}

Two exploratory underwater projects have been initiated in recent years, one in Cantabria and the other in Gibraltar, both involving a combination of underwater mapping and diver exploration.

Starting in the north, the project 'El Paleolítico Sumergido: Paisajes y Poblamiento Prehistóricos en la Plataforma Continental Cantábrica' (P5 Cant) (The Submerged Palaeolithic: Prehistoric Landscape and Human Settlement on the Cantabrian Continental Shelf) was carried out between 2015 and 2017.

As noted earlier, there are challenges to underwater exploration in this area because of variable sea conditions, frequent poor weather and the likelihood of erosion of underwater material by strong currents, but also advantages because of the high density of known sites on land that provide clues to target areas for underwater survey.

The aim of the P5 Cant Project was to test for the presence of submerged archaeology, and three areas were selected for surveying according to the following criteria:

- Shallow waters $(<30 \mathrm{~m})$.

- Existence of karst massifs, particularly where the caves faced inland (towards the south).

- Proximity to significant concentrations of onland Palaeolithic sites.

- Association with rapid transgression phases or with former estuaries and bays.

- Absence of large sand banks.
Areas considered most promising according to these criteria were around the karst massif of Mt. Buciero in Santoña, the vicinity of the Cape Mayor and the Santander Bay and the Cuchía area between the palaeovalleys of the Rivers Besaya and Pas. With the means available for the project, only one of these could be explored intensively, and the Cape Mayor-Santander Bay sector was chosen because of its optimal conditions. Surveying focused on two areas with detailed bathymetric survey using a multibeam echosounder (Reson SeaBat 7125), RTK (RealTime Kinematic) techniques and the production of digital elevation models (Fig. 13.4).

Using this bathymetry, two underwater survey campaigns were carried out, one of them more extensive, with a 'Triggerfish' model ROV of the 'Deep Ocean Engineering' company, directed by Xabier Guinda of the Hydraulic Institute at the University of Cantabria, and the other by diving, led by the archaeologist Pablo Saiz Silió and his team. These explorations succeeded in locating a series of places with potential for the conservation of Palaeolithic or Mesolithic remains: caves (Fig. 13.5), rockshelters and other karst forms (dolines, canyons), and some anomalous concentrations of mollusc shells. In addition, numerous sediment and rock samples were collected and, together with the bathymetric information, this has identified the continuation under the sea of geological and geomorphological structures known on land (Fig. 13.6; Sánchez Carro et al. 2017).

To sum up, the P5 Cant Project was able to produce worthwhile results in the reconstruction of the landscape and geological structure and the location of numerous sites with potential for future research. No less important has been the refinement of the methodology and the formation and training of a highly motivated interdisciplinary team with which the topic can be addressed in the future on realistic foundations.

In Gibraltar, a programme of underwater exploration was initiated in 2005 , as a pilot project involving collaboration between the University of York, the Hampshire and Wight Trust for Maritime Archaeology and the Gibraltar Museum with a follow-up season in 2008 including exca- 


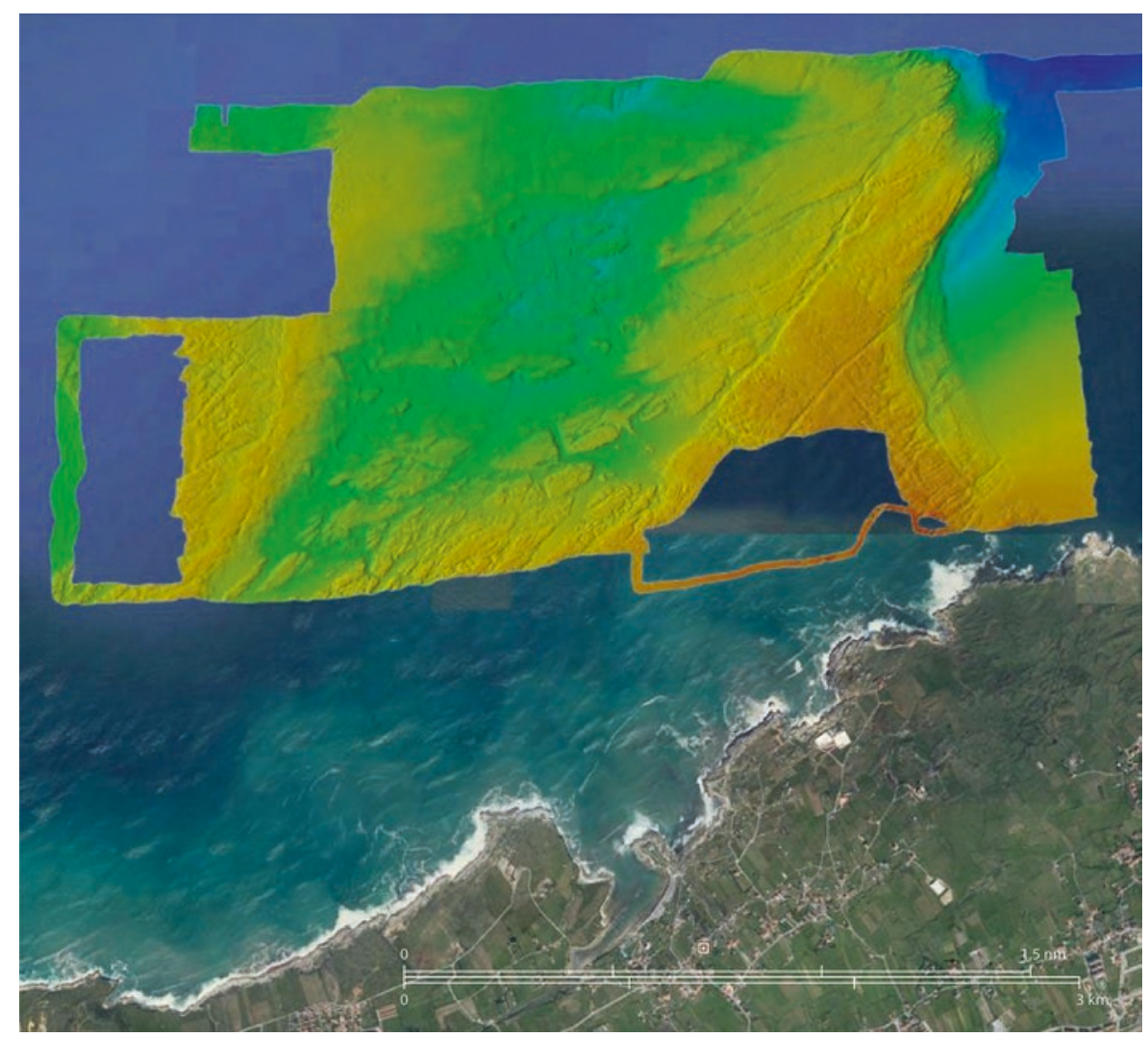

Fig. 13.4 High-resolution bathymetry of La Vaca area, northwest of Santander. Image by V. Bruschi, based on I. Galpasoro

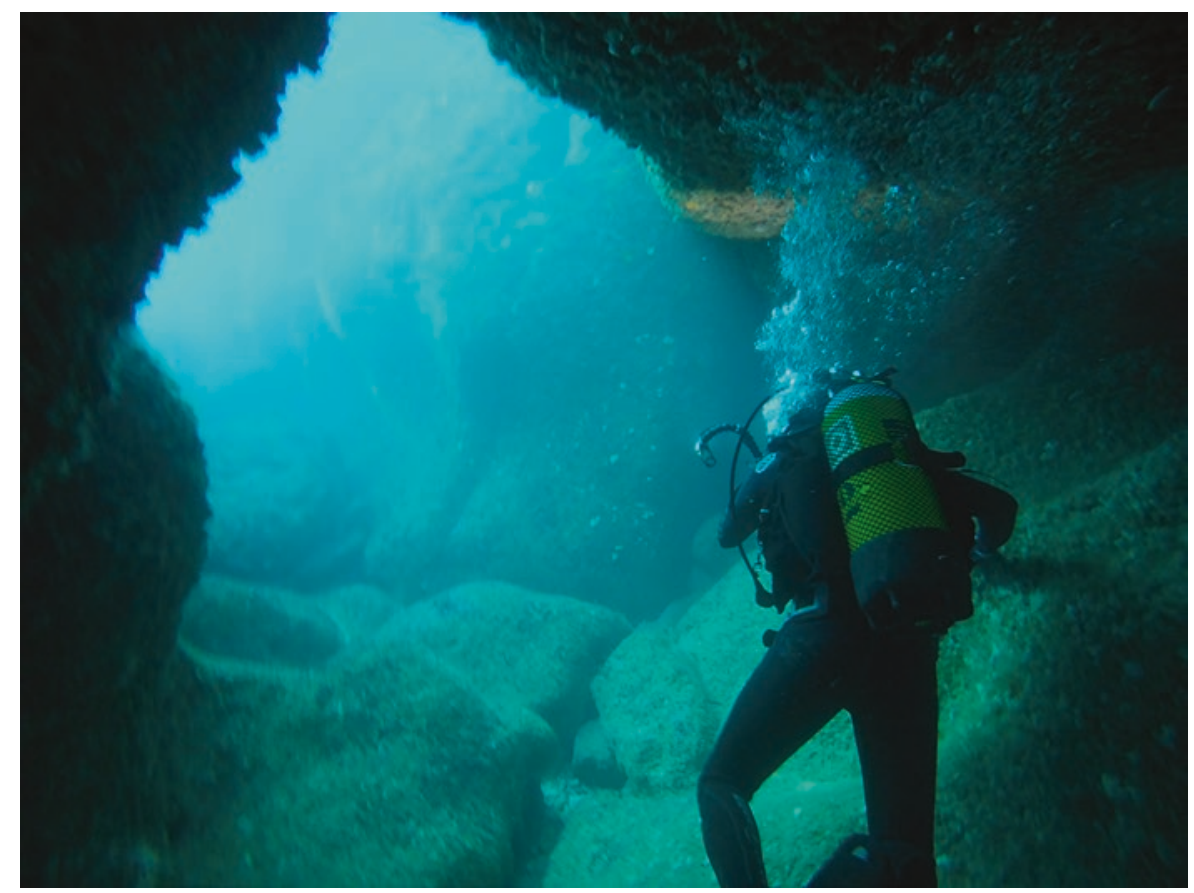

Fig. 13.5 Exploring a submerged cave between the islets of Mouro and La Corbera, near Santander. Photo by P. Saiz Silió 


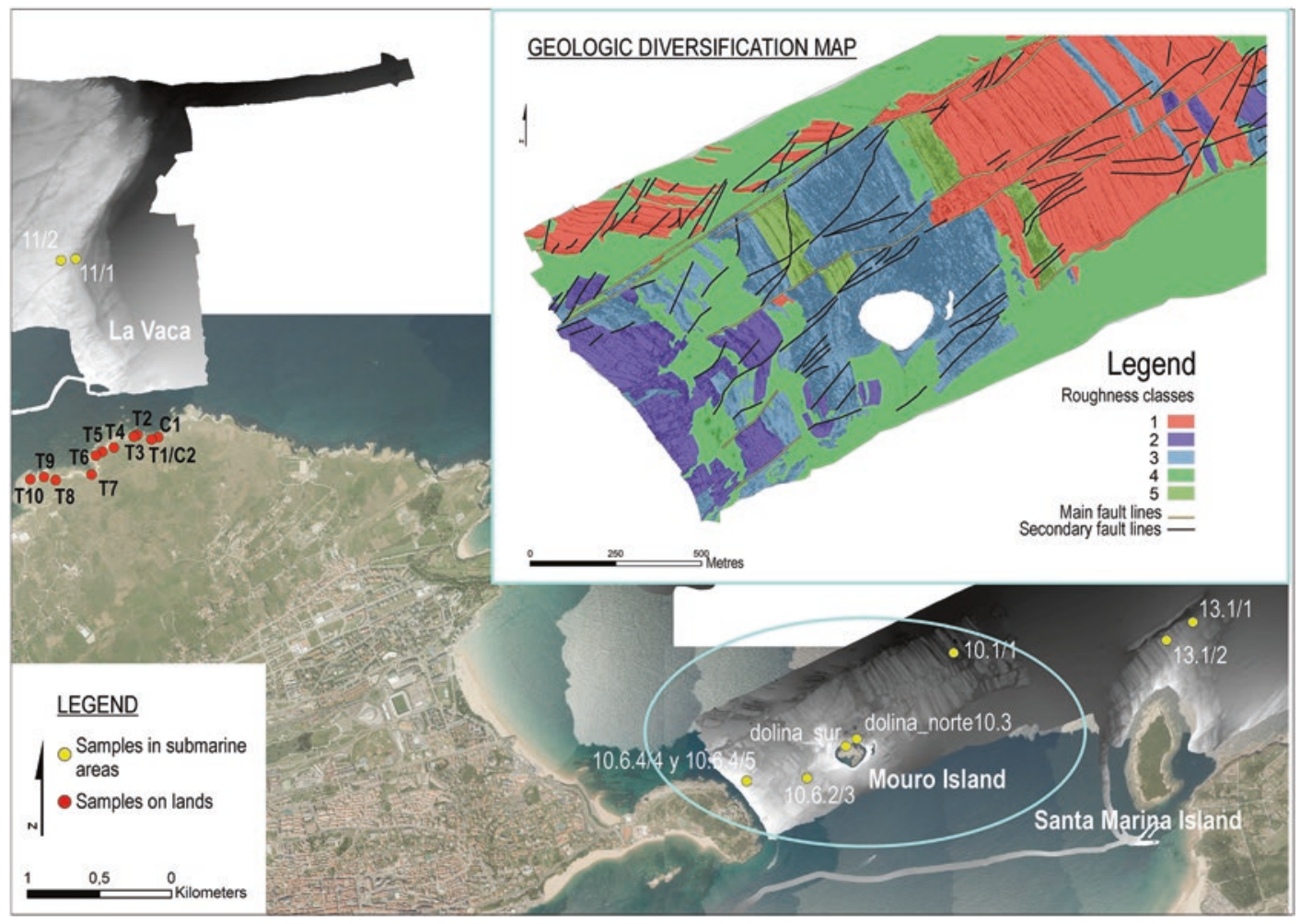

Fig. 13.6 Sampling programme for analysis of the underwater geology in the Cape Mayor-Santander Bay region. Sampling area and rugosity map after an ArcGis analysis showing the alternation of lithology and the continuity of fractures (corresponding to the blue circle in map). After Sánchez Carro et al. 2017

vation of an underwater cave (Bailey 2011). Gibraltar has many coastal caves including Gorham's Cave, Vanguard Cave, Devil's Tower and Forbes Quarry, all of which are famous for their Neanderthal fossils and archaeological sequences (Stringer et al. 2000; Finlayson et al. 2006). The submerged shelf around the Gibraltar Rock forms a relatively compact area, no wider than about 4-5 km, suitable for a detailed underwater landscape survey. Underwater work included landscape survey of most of the Gibraltar shelf using multibeam, sub-bottom profiling and side scan, diver mapping of the caves and their immediate surroundings and diver inspection of ridges and pinnacles on the eastern side of the shelf (Fig. 13.7). A submerged reef, known as Vladi's Reef lies about $200 \mathrm{~m}$ offshore and extends over a distance of c. $2 \mathrm{~km}$. A cliff on the north side of the ridge contains a number of cave openings at its base at a depth of about 18-22 m below present sea level, formed by marine solution during an earlier period of high sea level. The two largest of these are clearly large enough for human occupation: Finlayson cave measuring $12 \mathrm{~m}$ wide, $4.5 \mathrm{~m}$ deep and $1.8 \mathrm{~m}$ high from the cave roof to the top of the infill at its entrance and Momber Cave $3.3 \mathrm{~m}$ wide, $3.6 \mathrm{~m}$ deep and $1.5 \mathrm{~m}$ high. These caves appeared on preliminary inspection to have a cave fill, and their aspect, facing away from the open sea and towards the mainland shoreline, suggested the possibility of discovering terrestrial deposits that had been protected from wave erosion during sea-level rise. Preliminary excavations were undertaken at Momber Cave, selected because it was judged to have a better prospect of preserving terrestrial deposits, and a trench $2 \mathrm{~m} 1 \mathrm{~m} \times 0.6 \mathrm{~m}$ deep was excavated in the mouth of the cave (Fig. 13.8). The deposits comprise marine cobbles and sands, but further excavation was impeded by closely 
Fig. 13.7 Topography of the continental shelf around the Gibraltar Peninsula, showing Vladi's Reef and other submerged features. (a) General depth contours. (b) Close-up of Vladi's Reef showing detailed bathymetry and location of underwater caves. After Bailey 2011,

Figs. 10 and 11, p. 323

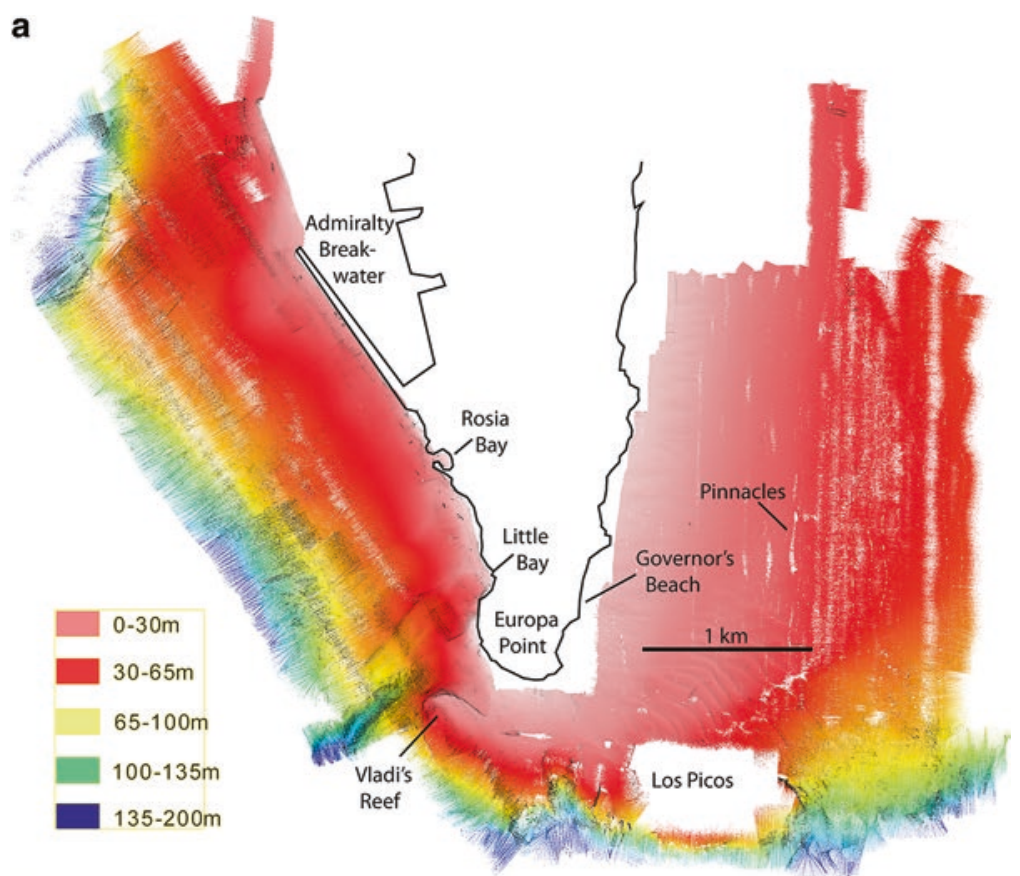

b

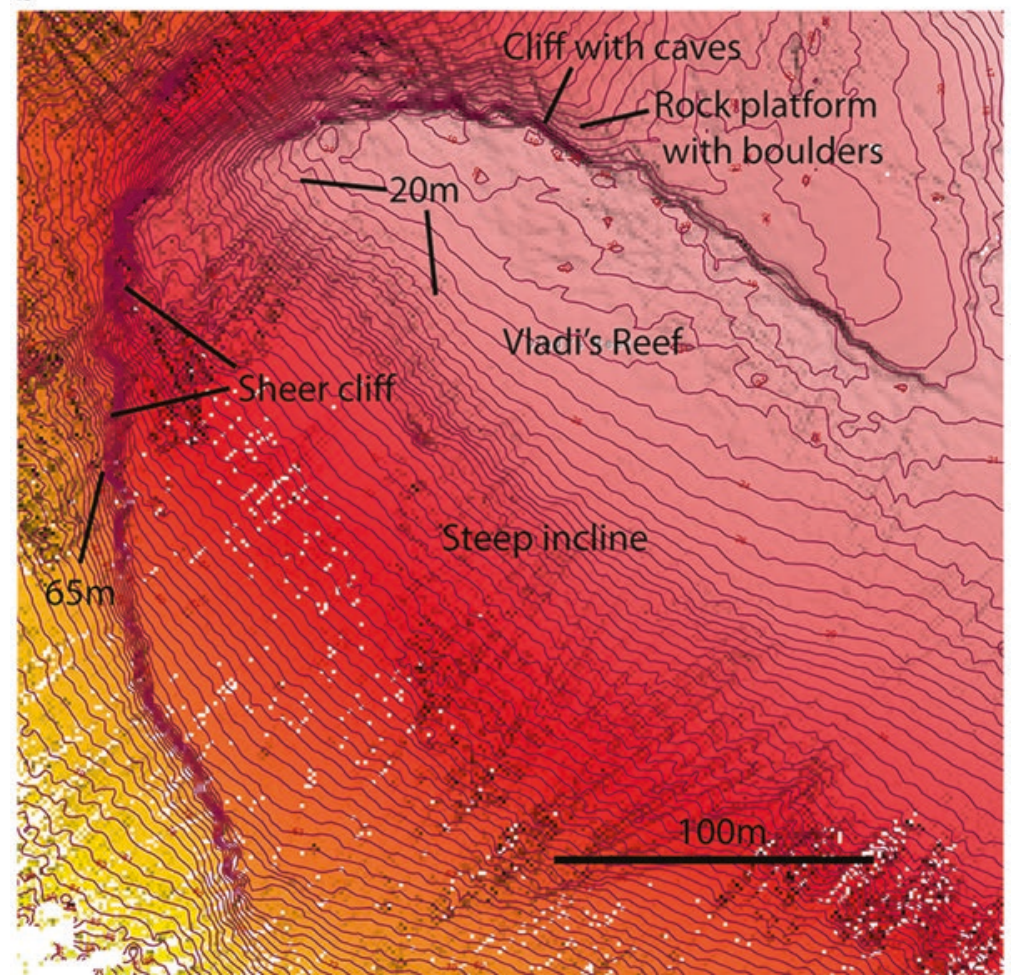

packed boulders at the base of the trench. Major engineering solutions will be required to discover whether terrestrial deposits are preserved beneath these boulders or beneath the boulder field immediately in front of the cave entrance, and no further work has been undertaken. This research 


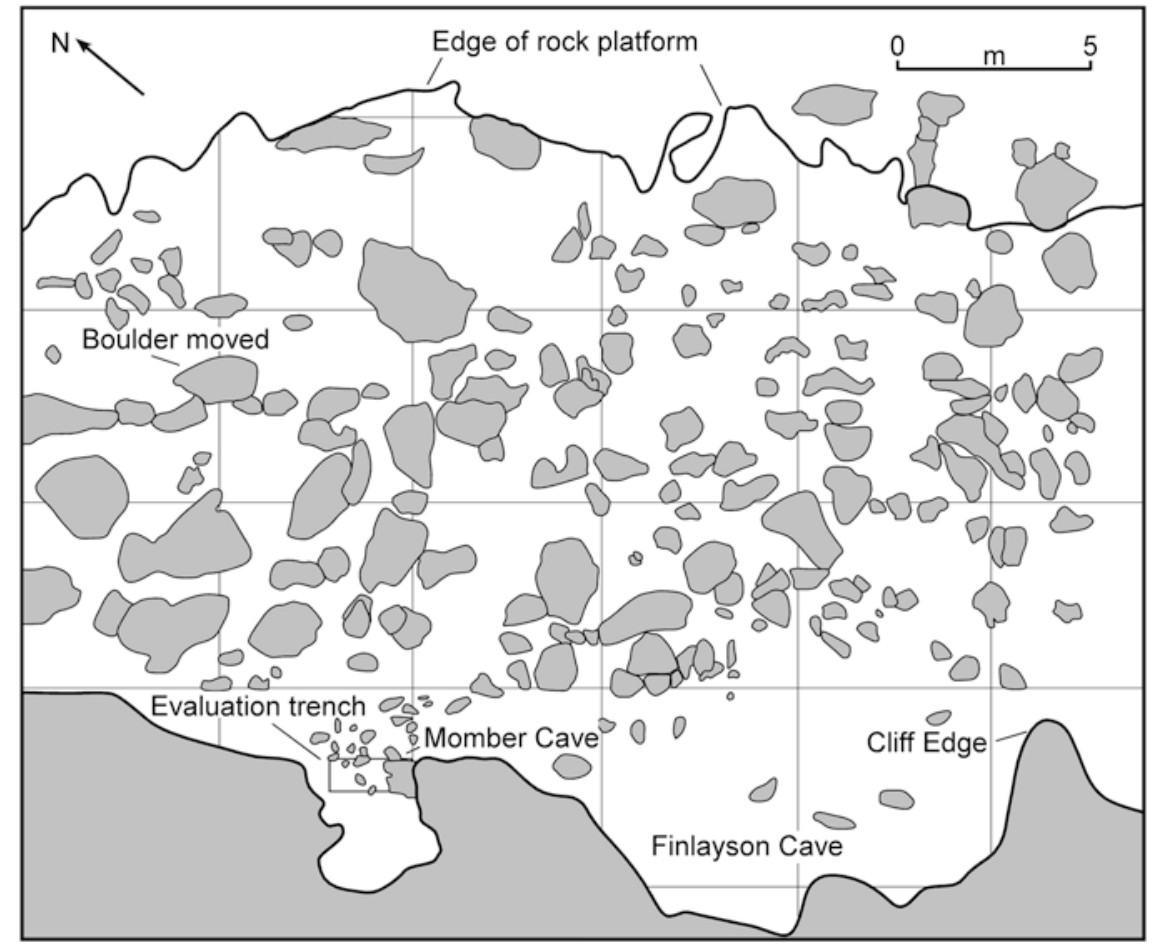

Fig. 13.8 Map of the submerged features on the north side of Vladi's Reef after 2005 survey and excavation. After Bailey 2011, Fig. 12, p. 324

constituted pioneering work on excavation in deep submerged caves, providing experience in the varied technical challenges of this kind of archaeological investigation.

\subsection{Concluding Remarks}

The Spanish continental shelf holds great potential for archaeological exploration aimed at finding and studying prehistoric sites, particularly Upper Palaeolithic deposits. The survey projects carried out in Cantabria and Gibraltar demonstrate both the challenges and the opportunities of systematic underwater survey. In both cases, the results have provided a better understanding of localised topographic features exposed at lower sea levels and targets suitable for more detailed archaeological investigation and excavation. It is to be hoped that these will be continued as other sectors of the coast are explored. Only in that way will it be possible to approach a fuller understanding of coastal occupation by Pleistocene and early Holocene communities and analyse the use of the littoral environment by hunter-gatherer societies during these earlier periods on a more realistic basis.

Acknowledgements The P5 Cant Project was funded by 'Cantabria Explora', a programme of the Parliament of Cantabria, and included the collaboration of researchers of the Universities of Cantabria (Raúl Medina, Sonia Castanedo, Xabier Guinda, Miguel A. Sánchez Carro, Viola Bruschi, Luis C. Teira, Carlos Duarte, Sara Núñez and Sheila Abada), Barcelona (Miquel Canals, Galderic Lastras, David Amblàs and Xavier Rayo), Salamanca (Esteban Álvarez-Fernández), Burgos (Eneko Iriarte) and La Rioja (Miguel Ángel Fano), the Basque Country (Alejandro Cearreta) and University College Dublin (Frank McDermott); the National Council for Scientific Research-CSIC (José Antonio López); the Spanish Oceanography Institute-IEO (Jesús Rivera); the Prehistory and Archaeology Museum of Cantabria-MUPAC (Roberto Ontañón); and Wessex Archaeology (Inés López-Dóriga), with the technical support of the underwater archaeologist Pablo Saiz Silió for the sampling and diving exploration and of Ibon Galpasoro, of Azti Tecnalia, for the multibeam 
bathymetry. The underwater work on Gibraltar was funded by grants from the Natural Environment Research Council of the UK (NERC) and the Arts and Humanities Research Council of the UK (AHRC), with offshore data supplied by IX Survey Ltd. and the participation of Geoff Bailey, University of York; Darren Fa, Clive Finlayson and Geraldine Finlayson of the Gibraltar Museum; Garry Momber, Julie Satchell and Lawrence Moran of the Maritime Archaeology Trust; Nicholas Flemming of the National Oceanographic Institute, Southampton; and Joaquín Rodríguez-Vidal, University of Huelva. Special thanks are due to Geoff Bailey, who has kindly provided information on this project for this chapter.

\section{References}

Alcalde del Río H, Breuil H, Sierra L (1911) Les cavernes de la région Cantabrique (Espagne), Imp. Vve A. Chêne, Monaco

Almagro M (1940) El hallazgo de la ría de Huelva y el final de la Edad del Bronce en el Occidente de Europa. Ampurias 2:85-143

Almagro M (1958) Depósito de la la ría de Huelva. Inventaria Archaeologica, pp 1-4

Altuna J (1997) Ekain y Altxerri: Dos santuarios paleolíticos en el País Vasco. Haranburu, San Sebastián

Álvarez-FernÁndez E (2011) Humans and marine resource interaction reappraised: archaeofauna remains during the late Pleistocene and Holocene in Cantabrian Spain. J Anthropol Archaeol 30(3):327-343

Álvarez-FernÁndez E, Carriol RP, JordÁ JF, Aura JE, Avezuela B, Badal E, Carrión Y, García-Guinea J, Maestro A, Morales JV, Pérez G, Pérez-Ripoll M, Rodrigo MJ, Scarff JE, Villalba MP, Wood R (2014) Occurrence of whale barnacles in Nerja cave (MÁlaga, southern Spain): indirect evidence of whale consumption by humans in the upper Magdalenian. Quat Int 337:163-169

Aparicio J (1975) Los yacimientos prehistóricos de la Albufera de Anna (Valencia). In: XIII Congreso Nacional de Arqueología, Secretaría de los Congresos Arqueológicos Nacionales, Zaragoza, pp 191-198

Arias P, Fano MÁ (2009) ¿Mesolítico Geométrico o Mesolítico con geométricos? El caso de la región Cantábrica. In: Utrilla P, Montes L (eds) El Mesolítico Geométrico en la Península Ibérica. Universidad de Zaragoza, Zaragoza, pp 69-91

Arias P, Ontañón R, Polanco JA, Setién J, Rovira S, Montero I (2005) Aproximación a la tecnología metalúrgica durante el Calcolítico y la Edad del Bronce de Cantabria. In: González Morales MR, Solórzano J (eds) II Encuentro de Historia de Cantabria. Servicio de Publicaciones de la Universidad de CantabriaParlamento de Cantabria, Santander, pp 53-77

Bailey GN (2011) Continental shelf archaeology: where next? In: Benjamin J, Bonsall C, Pickard C, Fischer A (eds) Submerged prehistory. Oxbow Books, Oxford, pp 311-331

Bailey GN, Craighead A (2003) Late Pleistocene and early Holocene coastal palaeoeconomies: a reconsideration of the molluscan evidence from Northern Spain. Geoarchaeology Int J 18(2):175-204

Blánquez JJ, Martínez Maganto J (1993) Historia de la Arqueología subacuástica en España. In: Martínez Lillo S, Blánquez J (eds) II Curso de Arqueología subacuática. Universidad Autónoma de Madrid, Madrid, pp 15-53

Blas MÁ, González Morales MR, Márquez Uría MC, Rodríguez Asensio JA (1978) Picos asturienses de yacimientos al aire libre en Asturias. Boletín del Instituto de Estudios Asturianos 93-94:335-356

Bosch À, Chinchilla J, Tarrús J (2000) El poblat lacustre del neolític antic de la Draga. Excavacions de 1990 a 1998. In: Monografies del CASC 2, Centre d'Arqueologia Subaquàtica de Catalunya, Girona

Bosch À, Chinchilla J, Tarrús J (2011) El poblat lacustre del neolític antic de la Draga. Excavacions 2000-2005. In: Monografies del CASC 9, Centre d'Arqueologia Subaquàtica de Catalunya, Girona

Bosch À, Buxó R, Chinchilla J, Palomo A, Piqué R, Saña M, Tarrús J, Terradas X (2012) El jaciment neolític lacustre de la Draga (Banyoles, Pla de l'Estany). Ajuntament de Banyoles, Banyoles

Bradley R (1990) The passage of arms. An archaeological analysis of prehistoric hoards and votive deposits. Cambridge University Press, Cambridge

Brandherm D (2007) Las espadas del Bronce Final en la Península Ibérica y Baleares. Prähistorische Bronzefunde, IV, 16. Franz Steiner, Stuttgart

Brandherm D, Burgess C (2008) Carp's-tongue problems. In: Verse F, Knoche B, Graefe J, Hohlbein M, Schierhold K, Siemann C, Uckelmann M, Woltermann G (eds) Durch die Zeiten, Festschrift für Albrecht Jockenhövel zum 65. Geburstag. Marie Leidorf, Rahden/Westfalen, pp 133-168

Burgess C, O'Connor B (2008) Iberia, the Atlantic Bronze Age and the Mediterranean. In: Celestino S, Rafel N, Armada X-L (eds) Contacto cultural entre el Mediterráneo y el Atlántico (siglos XII-VIII anr). La precolonización a debate. Madrid: CSIC, Escuela Española de Historia y Arqueología en Roma, Serie Arqueológica 11:41-58

Canals M, Cacho I, Carozza L, Casamor JL, Lastras G, Sanchez-Vidal A (2017) The Western Mediterranean Sea. In: Flemming NC, Harff J, Moura D, Burgess A, Bailey GN (eds) Submerged landscapes of the European continental shelf: quaternary paleoenvironments. Wiley, Chichester, pp 301-331

Casado JL, García-Castrillo G, Gómez Vega B, Sarabia P (1992) Arqueología subacuática en Cantabria. Un patrimonio secular en peligro, Sociedad Estatal para la Ejecución de programas del Quinto CentenarioDiputación Regional de Cantabria-Puerto de Santander-Universidad de Cantabria, Santander 
Corchón MS (ed) (2017) La cueva de las Caldas (Priorio, Oviedo): Ocupaciones magdalenienses en el valle del Nalón. Universidad de Salamanca, Salamanca

Corchón MS, Mateos A, Álvarez E, Peñalver E, Delclòs X, van der Made J (2008) Ressources complémentaires et mobilité dans le Magdalénien cantabrique. Nouvelles données sur les mammifères marins, les crustacés, les mollusques et les roches organogènes de la Grotte de Las Caldas (Asturies, Espagne). Anthropologie 112:284-327

Cortés M, Morales A, Simón MD, Lozano MC, Vera JL, Finlayson C, Rodríguez J, Delgado A, Jiménez FJ, Martínez F, Martínez MA, Pascual AJ, Bergadà MM, Gibaja JF, Riquelme JA, López JA, Rodrigo M, Sakai S, Sugisaki S, Finlayson G, Fa DA, Bicho NF (2011) Earliest known use of marine resources by Neanderthals. PLoS One 6(9):e24026

Cortés-Sánchez M, Morales-Muñiz A, Simón Vallejo MD, Bergadà-Zapata MM, Delgado-Huertas A, LópezGarcía P, López-Sáez JA, Lozano-Francisco MC, Riquelme-Cantal JA, Roselló-Izquierdo E, SánchezMarco A, Vera-Peláez JL (2008) Palaeoenvironmental and cultural dynamics of the coast of Málaga (Andalusia, Spain) during the Upper Pleistocene and early Holocene. Quat Sci Rev 27(23-24):2176-2193

Daura J, Sanz M, Pike AWG, Subirà ME, Quam R, Fullola JM, Arsuaga JL (2005) A Neandertal mandible from the Cova del Gegant (Sitges, Barcelona, Spain). J Hum Evol 49(1):56-70

Daura J, Sanz M, Pike AWG, Subirà ME, Fornós JJ, Fullola JM, Julia R, Zilhão J (2010) Stratigraphic context and direct dating of the Neandertal mandible from Cova del Gegant (Sitges, Barcelona). J Hum Evol 59(1):109-122

Fano MÁ (2004) Las sociedades del Paleolítico en la región Cantábrica. Diputación Foral de Bizkaia, Bilbao

Finlayson C, Giles Pacheco F, Rodríguez Vidal J, Fa DA, Gutierrez López M, Santiago Pérez A, Finlayson G, Allue E, Baena Preysler J, Cáceres I, Carrión J, Fernández Jalvo Y, Gleed-Owen CP, Jimenez Espejo FJ, López P, López Sáez JA, Riquelme Cantal JA, Sánchez Marco A, Giles Guzman F, Brown K, Fuentes N, Valarino CA, Villalpando A, Stringer CB, Martinez Ruiz F, Sakamoto T (2006) Late survival of Neanderthals at the southernmost extreme of Europe. Nature 443:850-853

González Morales MR (1982) El Asturiense y otras culturas locales. La explotación de las áreas litorales de la región cantábrica en los tiempos epipaleolíticos. Ministerio de Cultura, Santander

Jorge M (1953) Hacia una sistematización de la Edad del Bronce en la actual provincia de Santander. Altamira 1, 2, 3:242-282

Martínez Díaz B (1992) Legislación en torno a la protección del patrimonio arqueológico subacuático en España. Cuadernos de Arqueología marítima 1:13-26

Martínez Díaz B (1993) La protección del Patrimonio arqueológico subacuático. In: Martínez Lillo S,
Blánquez J (eds) II Curso de Arqueología subacuática. Universidad Autónoma de Madrid, Madrid, pp 121-143

Matamoros P, Carrascosa B, Cerrillo E (2013-2015) La catalogación del Patrimonio arqueológico subacuático en la cuenca extremeña del Tajo. Primeros pasos hacia su salvaguarda Arché Publicación del Instituto Universitario de Restauración del Patrimonio de la Universitat Politècnica de València, 8-10:137-144

Meijide G (1988) Las espadas del Bronce Final en la Península Ibérica, Servicio de Publicación e Intercambio Científico da Universidade de Santiago de. Compostela, Santiago de Compostela

Montes R (1985) El ciclo transgresión-regresión y hundimientos costeros en el sureste español. Su influencia en asentamientos pleistocenos. In: VI Congreso Internacional de Arqueología Submarina, Cartagena, 1982. Subdirección General de Arqueología y Etnografía, Madrid, pp 99-110

Montes R (1989) La grotte "de Los Aviones" Cartagena (Espagne). Bulletin de la Société préhistorique française 86:40-44

Montes R (1991) La cueva de los Aviones. Un yacimiento del Paleolítico Medio (Cartagena, España). In: Excavaciones y prospecciones en la región de Murcia 1985-1986. Consejería de Cultura, Educación y Turismo, Murcia, pp 35-58

Morales A, Roselló E (1984-1985) Algunas consideraciones de índole zoológica en torno al pez representado en la cueva de El Pindal. Ars Praehistorica 3-4:247-251

Morales A, Roselló E, Hernández F (1998) Late Upper Palaeolithic subsistence strategies in southern Iberia: tardiglacial faunas from Cueva de Nerja (Málaga, Spain). Eur J Archaeol 1(1):9-50

Morales JV, Pérez-Ripoll M, Jordá JF, Álvarez-Fernández E, Maestro A, Aura, JE (in press) Mediterranean monk seal hunting in the regional Final Magdalenian of Southern Iberia. A study of the Cueva de Nerja site. Quaternary International, Málaga

Moura D, Gomes A, Horta J (2017) The Iberian Atlantic margin. In: Flemming NC, Harff J, Moura D, Burgess A, Bailey GN (eds) Submerged landscapes of the European continental shelf. Quaternary paleoenvironments. Wiley-Blackwell, Oxford, pp 281-300

Nieto X (2009) La aqueología subacuática en España. In: Nieto X, Cau MÁ (eds) Arqueologia Nàutica Mediterrània. CASC, Girona, pp 17-25

Nieto X, Bethencourt M (2014) Arqueología subacuática española. Actas del I Congreso de Arqueología náutica y subacuática Española, Cartagena, 14, 15 y 16 de marzo de 2013. Universidad de Cádiz, Cádiz

Peña A (1985) Neue bronzeliche Funde in Museo Provincial de Pontevedra. Madrider Mitteilungen 26:22-28

Piqué R, Palomo A, Terradas X, Tarrús J, Bosch À, Chinchilla J, Bodganovic I, López O, Saña M (2015) Characterizing prehistoric archery: technical and functional analyses of the Neolithic bows from La Draga (NE Iberian Peninsula). J Archaeol Sci 55:166-173 
Rivero O (2015) Art mobilier des chasseurs magdaléniens à la façade atlantique. Etudes et Recherches Archéologiques de l'Université de Liège, Liège

Ruiz A (2014) Entre el Cantábrico y los Pirineos: El conjunto de Altxerri en el contexto de la actividad gráfica magdaleniense. Nadir, Santander

Ruiz-Gálvez ML (1982) Nueva espada dragada en el río Ulla. Armas arrojadas a las aguas Ampurias 36:181-183

Ruiz-Gálvez ML (1995) Ritos de paso y puntos de paso. La Ría de Huelva en el mundo del Bronce Final Europeo. In: Complutum Extra 5, Servicio de Publicaciones de la Universidad Complutense, Madrid

San Nicolás M, Martínez C (1987) Prospecciones arqueológicas en la cueva C-6, cabo Cope, Águilas. In: Excavaciones y prospecciones arqueológicas. Servicio Regional de Patrimonio Histórico, Murcia, pp 10-16

Sánchez Carro MÁ, Bruschi V, Saiz Silió P, Iriarte E, Galpasoro I, Arias P (2017) El Paleolítico sumergido: batimetría y caracterización geológica del fondo marino en zonas próximas a Santander para la localización de yacimientos arqueológicos. Geo-Temas $17: 35-38$

Straus LG (1992) Iberia before the Iberians. The stone age prehistory of Cantabrian Spain. University of New Mexico Press, Albuquerque

Straus LG (2018) The upper Paleolithic of Iberia. Trab Prehist 75(1):9-51

Straus LG, Clark GA (eds) (1986) La Riera Cave. Stone Age hunter-gatherer adaptations in northern Spain. Arizona State University, Tempe

Stringer CB, Barton RNE, Finlayson JC (eds) (2000) Neanderthals on the edge: papers from a conference marking the 150th anniversary of the Forbes' quarry discovery, Gibraltar. Oxbow, Oxford

Stringer CB, Finlayson JC, Barton RNE, FernandezJalvo Y, Caceres I, Sabin RC, Rhodes EJ, Currant AP, Rodriguez-Vidal J, Giles-Pacheco F, RiquelmeCantal JA (2008) Neanderthal exploitation of marine mammals in Gibraltar. Proc Natl Acad Sci U S A 105:14319-14324

Open Access This chapter is licensed under the terms of the Creative Commons Attribution 4.0 International License (http://creativecommons.org/licenses/by/4.0/), which permits use, sharing, adaptation, distribution and reproduction in any medium or format, as long as you give appropriate credit to the original author(s) and the source, provide a link to the Creative Commons licence and indicate if changes were made.

The images or other third party material in this chapter are included in the chapter's Creative Commons licence, unless indicated otherwise in a credit line to the material. If material is not included in the chapter's Creative Commons licence and your intended use is not permitted by statutory regulation or exceeds the permitted use, you will need to obtain permission directly from the copyright holder. 